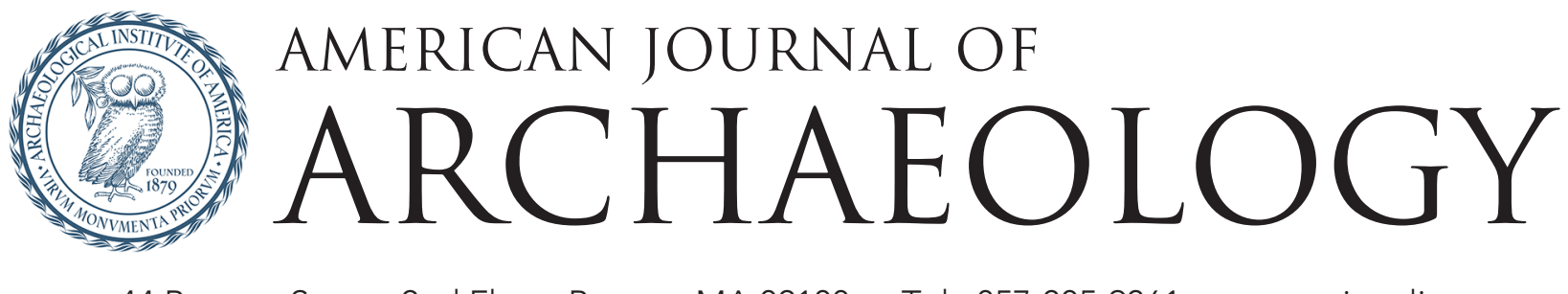

44 Beacon Street, 2nd Floor, Boston, MA 02108 • Tel.: 857-305-9361 • www.ajaonline.org

This article is (C) The Archaeological Institute of America and was originally published in AJA 121(4):511-525.

This e-print is supplied to the author for noncommercial use only, following the terms outlined in the accompanying cover letter. The definitive electronic version of the article can be found at:

www.jstor.org/stable/10.3764/aja.121.4.0511. 


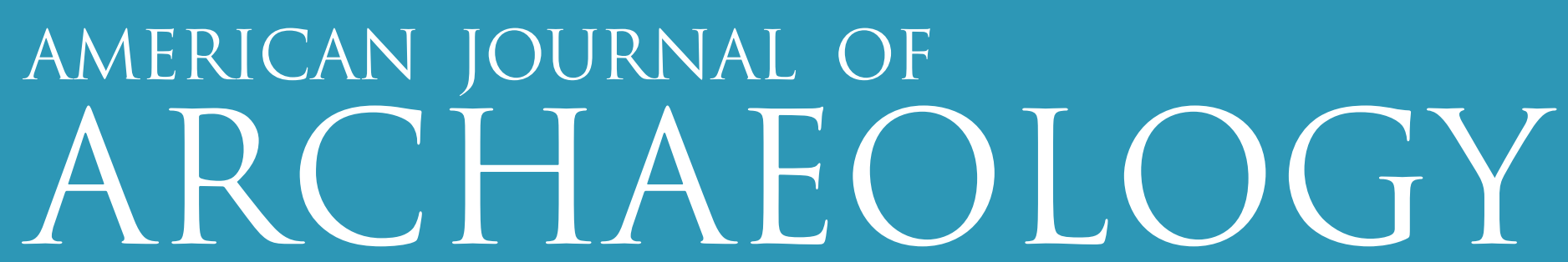

The Journal of the Archaeological Institute of America

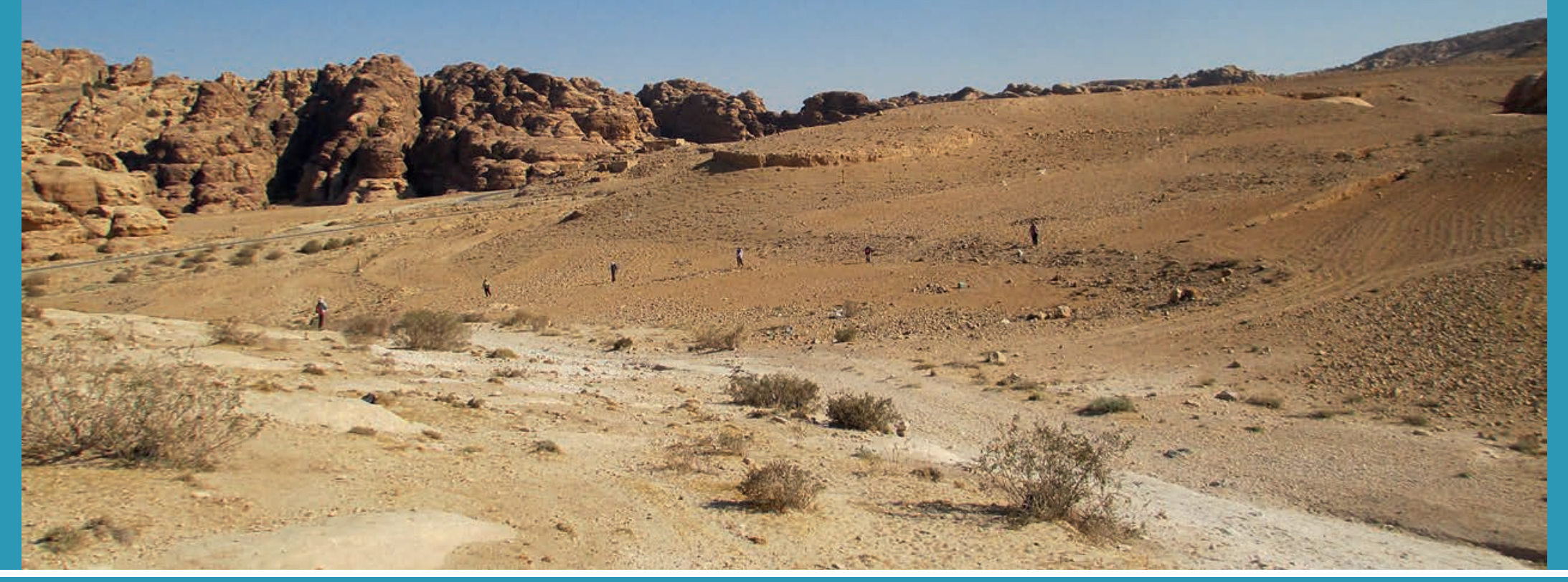




\title{
Talking Neolithic: Linguistic and Archaeological Perspectives on How Indo-European Was Implemented in Southern Scandinavia
}

\author{
RUNE IVERSEN AND GUUS KROONEN
}

\begin{abstract}
In this article, we approach the Neolithization of southern Scandinavia from an archaeolinguistic perspective. Farming arrived in Scandinavia with the Funnel Beaker culture by the turn of the fourth millennium B.C.E. It was superseded by the Single Grave culture, which as part of the Corded Ware horizon is a likely vector for the introduction of IndoEuropean speech. As a result of this introduction, the language spoken by individuals from the Funnel Beaker culture went extinct long before the beginning of the historical record, apparently vanishing without a trace. However, the Indo-European dialect that ultimately developed into Proto-Germanic can be shown to have adopted terminology from a non-Indo-European language, including names for local flora and fauna and important plant domesticates. We argue that the coexistence of the Funnel Beaker culture and the Single Grave culture in the first quarter of the third millennium B.C.E. offers an attractive scenario for the required cultural and linguistic exchange, which we hypothesize took place between incoming speakers of Indo-European and local descendants of Scandinavia's earliest farmers. ${ }^{1}$
\end{abstract}

\section{INTRODUCTION}

Language is an important part of human self-perception and a creator of identity among human groups through time, and, as such, language is an important factor in understanding cultural change in prehistory. Around 4000 B.C.E., large parts of northern Europe saw the introduction of Neolithic life represented by the appearance of domesticated animals and crops as well as polished flint and stone tools and new pottery forms such as funnel beakers (figs. 1,2). In southern Scandinavia, the Neolithic roughly covers the fourth and third millennia B.C.E., corresponding to the period ca. 4000-2000 B.C.E. or 4000-1700 B.C.E. depending on whether the final Late Neolithic, Late Neolithic II (ca. 2000-1700 B.C.E.), is considered part of the Neolithic or the earliest Bronze Age. ${ }^{2}$ The fourth millennium B.C.E. appears as a highly progressive and productive period in which we see the construction of a wide range of monuments (including the building of tens of thousands of megalithic tombs), a rich deposition practice, elaborate pottery styles, an expanding settlement pattern, and woodland clearance. Despite the evidence of a rich and ritually complex epoch, the fourth millennium B.C.E. was in cultural terms rather homogeneous and predominantly occupied by the Funnel Beaker culture. However, northern Europe is a region that saw profound cultural changes in the early third millennium B.C.E. In southern Scandinavia, the end of the Funnel Beaker culture overlapped with the emergence of Sub-Neolithic

American Journal of Archaeology Volume 121, Number 4

October 2017

Pages 511-25

DOI: 10.3764/aja.121.4.0511

www.ajaonline.org
${ }^{1}$ Figures are our own unless otherwise noted.

${ }^{2}$ For a detailed discussion on this matter, see Iversen 2015, 29-31. 


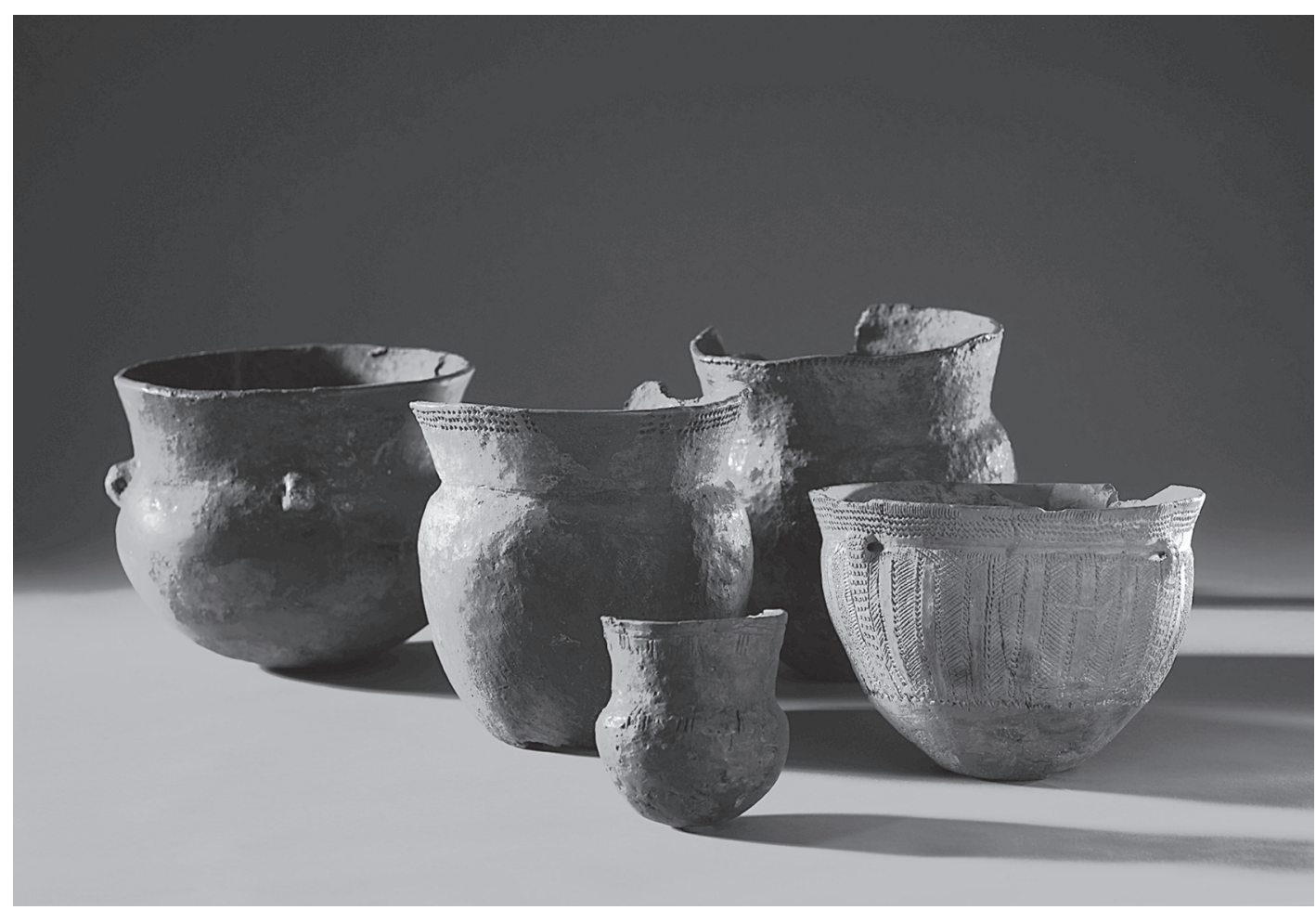

FIG. 1. A small selection of fourth-millennium B.C.E. Funnel Beaker pottery (A. Mikkelsen; courtesy National Museum of Denmark/CC-BY-SA).

Pitted Ware influences that reached the northern and eastern coastal areas of present-day Denmark from the Scandinavian Peninsula. From ca. 2850 B.C.E., early Corded Ware (Single Grave) societies appeared on the Jutland Peninsula and introduced among other things new burial customs, pottery shapes, amber ornaments, and new types of stone battle-axes (fig. 3).

The third millennium B.C.E. was a period of great material and cultural change, and language cannot be ignored as a factor when considering these changes. Instead, language is to be regarded as an integral part of them. Through its vocabulary, language is the medium for the transmission of new ideas, and it thus accumulates evidence for cultural change through the ages. This article combines the linguistic and archaeological evidence for innovations in subsistence strategies and material culture in the third millennium B.C.E. into a unified scenario. The aim is to determine when the speakers of the Indo-European dialect that later evolved into Proto-Germanic became established in northern Europe and southern Scandinavia. We envisage a scenario in which these speakers, having arrived in central and western Jutland together with Corded Ware cultural features, became integrated into and
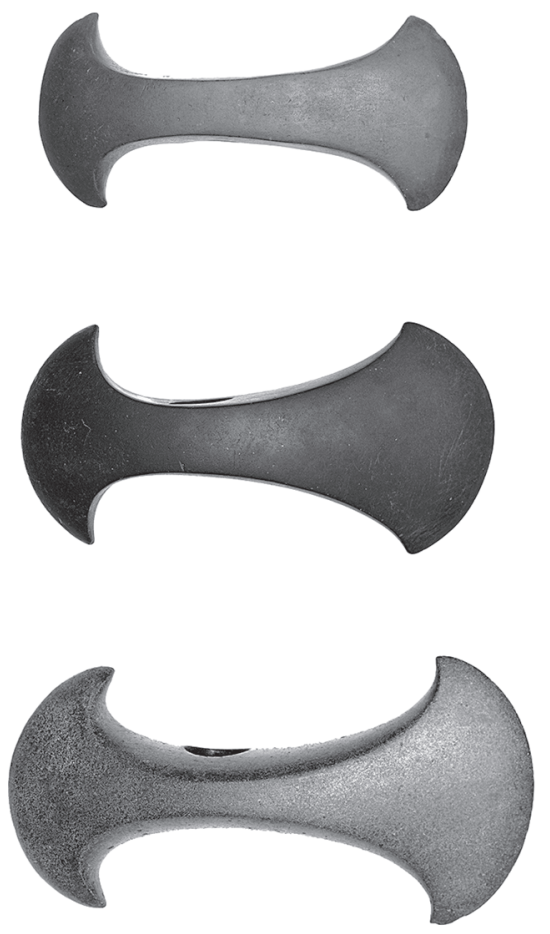

FIG. 2. Funnel Beaker stone battle-axes, so-called double-edged battle-axes, Middle Neolithic types (R. Fortuna and K. Ursem; courtesy National Museum of Denmark/CC-BY-SA). 
influenced by late Funnel Beaker culture groups, who according to our data spoke an unknown language that would become extinct before the start of the historical record. This extinct language, which we shall henceforth refer to as "Early European Neolithic," is the likely donor of an etymologically obscure set of Germanic terms for local flora and fauna and important plant domesticates that were absent in the parent language, Proto-Indo-European.

\section{THE INDO-EUROPEAN LANGUAGES AND THEIR PREHISTORY}

With the exception of Basque, Finnish, Estonian, and Hungarian, the modern linguistic landscape of Europe is almost entirely shaped by a single language family: Indo-European. This surprising linguistic unity is likely the result of a prehistoric cultural expansion that caused the extinction of many of the previously spoken languages. By the dawn of history we see a patchwork of Indo-European subdialects: Germanic, Celtic, Italic, Baltic, Slavic, Albanian, Armenian, and Greek (fig. 4). The modern European languages, such as Italian, German, Lithuanian, and Swedish, not to mention the highly globalized English, French, Spanish, and Russian, all evolved from these dialects. In Southwest Asia, too, Indo-European gave rise to large linguistic subgroups - that is, Indic and Iranian, whose oldest known relatives are Sanskrit, Avestan, and Old Persian. Some of the descendants of these languages, including Hindi, Urdu, Pashto, Farsi, and Kurdish, are now dominant in India, Afghanistan, Pakistan, and Iran.

\section{THE INDO-EUROPEAN HOMELAND QUESTION: THE ANATOLIAN HYPOTHESIS VS. THE STEPPE HYPOTHESIS}

The dominance of the Indo-European languages in Europe is a striking fact of history and immediately raises the question of how an entire continent could have become "Indo-Europeanized" in an age without mass communication. The magnitude of the shift implies the incursion of a profound prehistoric event. The origin of the European languages, unsurprisingly, has been and continues to be a matter of intense academic debate. Though a plethora of theories on the origin of the Indo-European languages have been formulated, ${ }^{3}$ there are currently only two prehistoric events that, in

${ }^{3}$ Cf. Gamkrelidze and Ivanov 1995; Alinei 2000; Ebbesen 2009; Demoule 2014.

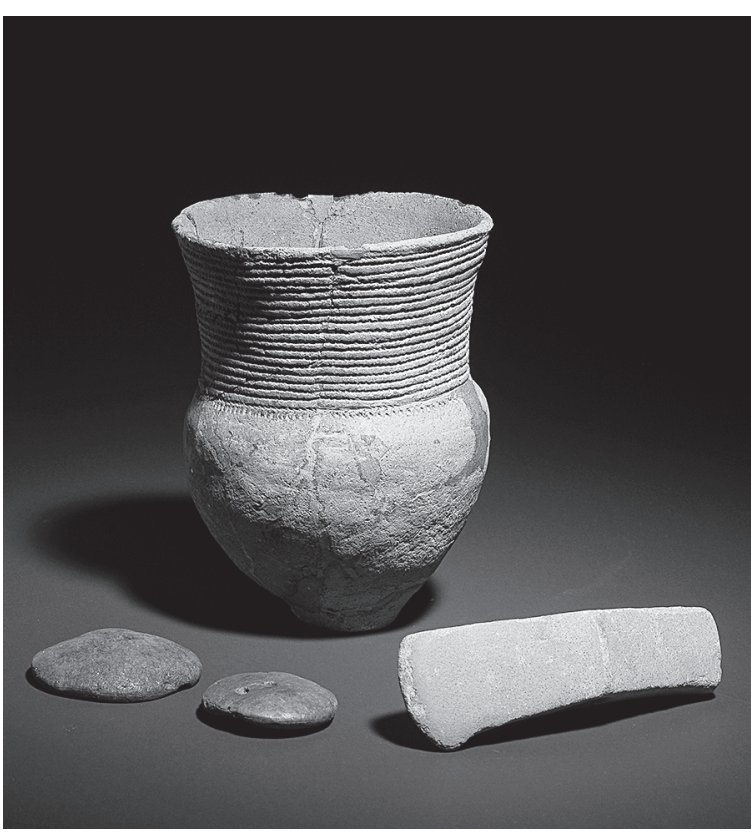

FIG. 3. Early Single Grave culture assemblage: cord-ornamented beaker, two perforated amber disks, and a stone battle-axe from a burial mound at Møbjerggårde, southeastern Jutland (R. Fortuna and K. Ursem; courtesy National Museum of Denmark/ CC-BY-SA).

the present academic debate, are considered plausible vectors for the dispersal of Indo-European speech: the Neolithization process (the Anatolian hypothesis) and the somewhat later migration from the Pontic-Caspian steppe into central Europe (the steppe hypothesis).

Archaeologist Colin Renfrew has argued that the Indo-European language spread together with agriculture from Anatolia. ${ }^{4}$ Certainly, the rise and spread of agricultural techniques marked a key turning point in the history of human society and had an enormous economic, societal, and possibly also linguistic impact. As it is put by the archaeologist T. Douglas Price, "farming changed everything." For much of human prehistory, hunting and gathering were the sole subsistence strategies. Small mobile groups, inhabiting large stretches of land, exploited large varieties of food sources whose availability shifted with the terrain and the seasons. These strategies changed radically when, in the 10th millennium B.C.E., inhabitants of the Fertile Crescent started adapting their habitat to the benefit of those plants and animals that constituted their diet.

\footnotetext{
${ }^{4}$ Renfrew 1987.

${ }^{5}$ Price 2013, 124.
} 


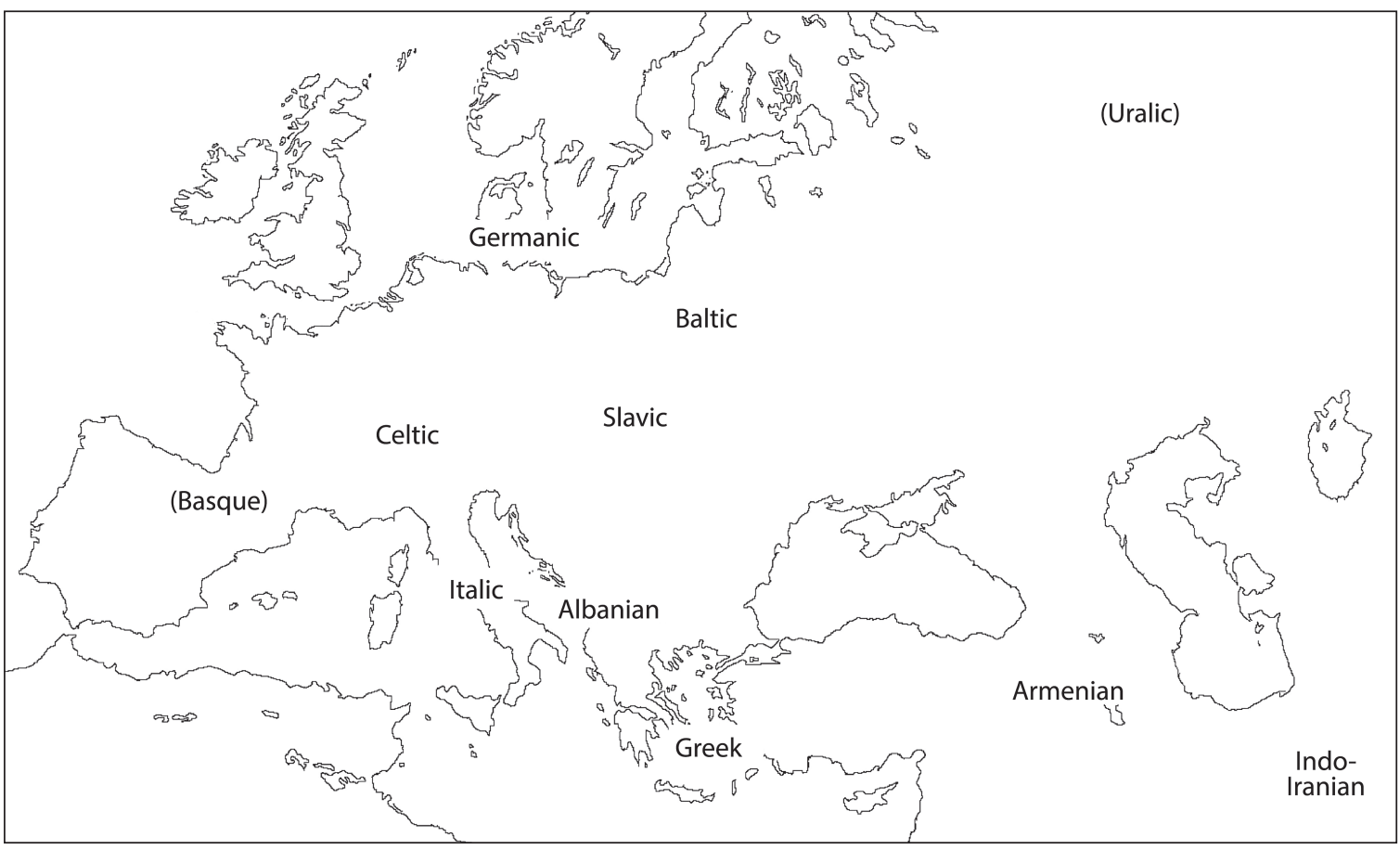

FIG. 4. The historical locations of the Indo-European languages in western Eurasia (not on this map: the extinct branches Anatolian and Tocharian). The parentheses indicate non-Indo-European languages.

The first eight crops to be domesticated, the socalled founder crops, comprised four pulses (peas, chickpeas, lentils, and bitter vetch), three cereals (emmer wheat, einkorn wheat, and barley), and the fiber plant flax. ${ }^{6}$ Around the same time, wild animals were tamed and kept in flocks. Goats were probably domesticated first, then sheep, pigs, and cattle. The importance of the domestication of plants and animals, though revolutionary itself, does not lie primarily in the acquisition of new food strategies but rather in the subsequent effects domestication had on societal structure. The first monumental buildings appeared. Land use was intensified; the available amount of food increased; and as population density soared societal structures became more complex. Pottery was introduced for cooking, for containing liquids, and for storage. By 7000 B.C.E., a completely new, Neolithic way of life had taken shape, one that soon after expanded into originally hunter-gatherer territories in Europe.

Obviously, the transition from a hunter-gatherer to a farming lifestyle may have had important linguistic repercussions, favoring the language of expanding

${ }^{6}$ Cf. Zohary and Hopf 2000, 241-59. agrarian communities over those of others. Based on various case studies it has indeed been established that farming populations are a common vector for the spread of languages worldwide. ${ }^{7}$ Also, while archaeologists have debated for more than a century whether the Neolithic expansion was driven purely by the adoption of new ideas (cultural diffusion) or by the arrival of actual farmers (demic diffusion), recent advances in archaeogenetics clearly favor a scenario in which agricultural techniques were introduced to local huntergatherer populations by immigrating groups of farming pioneers. ${ }^{8}$ Given the relative cultural and genetic homogeneity of these immigrating groups, it is indeed plausible that they spoke a single language or at least a set of closely related dialects of a single language family, which theoretically could have been Indo-European. In recent years, experimental lexicostatistic methods developed within linguistics have been used to estimate the original date and location of the Indo-European

\footnotetext{
${ }^{7}$ Diamond and Bellwood 2003; Bellwood 2005, 2011; Heggarty 2014.

${ }^{8}$ Malmström et al. 2009; Haak et al. 2010, 9 November; 2015; Fort 2012; Skoglund et al. 2012.
} 
protolanguage with the help of lexical evidence. The results of some of those studies were indeed compatible with the Anatolian hypothesis. ${ }^{9}$

Most Indo-Europeanists, however, have arrived at a different conclusion. Ever since the discovery of the Indo-European language family, they have worked to identify related words, or cognates, across the daughter languages. When a word occurs in two or more branches, it may have been inherited from the ProtoIndo-European parent. As a rule, the likelihood of a word being of Proto-Indo-European origin increases with the number of descendant languages in which it occurs. In addition, the likelihood increases with the spatial difference between two daughter languages. If, for instance, a word occurs in Indic and Germanic, it is more likely to be Indo-European than when it occurs only in Celtic and Germanic, as the geographic vicinity of the latter two branches heightens the probability of mutual borrowing or borrowing from a local third language. By painstakingly comparing the lexical similarities found in the different Indo-European branches, historical linguists have been able to reconstruct parts of the original Indo-European language vocabulary in considerable detail. ${ }^{10}$

The reconstructed lexicon provides important clues to the material culture and subsistence strategies of the Indo-Europeans, because when a specific word can be reconstructed this implies that the speakers were familiar with the concept referred to by this word. With the help of this so-called paleolinguistic method, the culture of the speakers of Proto-Indo-European can be approximated in both space and time. Since the language contains vocabulary related to dairy production ( ${ }^{*} g^{w} e h_{2}-u$ - "cow"; *h $h_{2}$ elǵ - "to milk"; * $d^{h} e-d^{h} h_{1}$ "sour milk"; ${ }^{*} t(e) n k$-lo- "buttermilk"; *tuH-ri- "cheese"), to wool production ( ${ }^{*} h_{3}$ eu-i- "sheep"; ${ }^{*} h_{2}$ eg s $^{w}$-no- "lamb"; *h $h_{2} u l h_{1}$-no- "wool"), to horse breeding ( ${ }^{*} h_{1}$ ekuo- "horse"; *polH-"foal"; *demh - "to tame"), and to wagon technology ( ${ }^{*} h_{2}$ urg-i- "wheel"; ${ }^{*} k^{w} e-k^{w} l-o$ - "wheel”; ${ }^{*} H$ rot-eh "wheel"; *h nob ${ }^{h}-e h_{2}$ - "nave"; ${ }^{*} h_{2} e k^{\prime} s-$ "axle"; ${ }^{*} h_{3}(o) i H-s-$ "thill”; *iug-o- "yoke"; *km-io-, "yoke pin, hame"), it must have been spoken no earlier than the Chalcolithic and at a location where all the aforementioned technological innovations were present (table 1). This supports the hypothesis that Proto-Indo-European was

\footnotetext{
${ }^{9}$ Bouckaert et al. 2012; Haak et al. 2015.

${ }^{10}$ Cf. Mallory and Adams 2006; Clackson 2007; Fortson 2010; Beekes and de Vaan 2011.
}

spoken by people associated with the pastoral-nomadic Yamnaya culture that stretched across the PonticCaspian steppe between 3300 and 2500 B.C.E. ${ }^{11}$ The coincidence of several technological innovations, including the invention of the wheel, the adoption of domesticated horses, and the introduction of dairy and wool production in this area, may have given the speakers of Indo-European a significant economic advantage over other cultural groups. Increased mobility certainly allowed for the establishment of long-distance networks through which Indo-European could have easily spread. ${ }^{12}$ The latest archaeogenetic evidence indeed confirms that there was a detectable influx of people from the steppes into central Europe in the early third millennium B.C.E. ${ }^{13}$

The Yamnaya pastoral-nomadic lifestyle also explains the relative paucity of Indo-European vocabulary for crops and land cultivation, which have proven to be far more difficult to reconstruct. While such terms are not completely absent (cf. *ieuo- "[unspecified] cereal"; ${ }^{*} \operatorname{ses}\left(h_{1}\right)$-io- "[unspecified] cereal"; * ǵrh -no- "grain, kernel"; *h erh $_{3}$ " to plow"; *kok-H- "[forked] branch, plow"), names for key founder crops such as flax and the primary legumes (lentils, peas, and chickpeas) typically cannot be reconstructed for Proto-Indo-European because the different Indo-European dialects use dissimilar and unrelated terms, terms that are typically also limited to specific regions in Europe or Asia. Such regional words have pervaded the literature on IndoEuropean linguistics, ${ }^{14}$ along with references to their problematic origins. ${ }^{15}$ The Indo-Europeans almost certainly had some knowledge of agricultural practices, in other words, probably through trade with the farming communities to the west of the Dnieper or the North Caucasus, but they possessed nowhere near the full crop assemblage that spread from the Fertile Crescent during the earliest phase of the Neolithization. ${ }^{16}$ From the linguistic perspective, the idea that the Indo-European languages could have spread from Anatolia along

\footnotetext{
${ }^{11}$ Gimbutas 1956, 1965; Mallory 1989, 183; Anthony 2007.

${ }^{12}$ Anthony 2007, 302; Kristiansen 2012.

${ }^{13}$ Allentoft et al. 2015; Haak et al. 2015; Kristiansen et al. 2017.

${ }^{14}$ Cf. Pokorny 1959-1969; Gamkrelidze and Ivanov 1995, 557-70; Mikić 2012, 4 September.

${ }^{15}$ Cf. Hester 1968; Schrijver 1991; Mallory and Adams 2006, 172; Dugan 2016, 20 December.

${ }^{16}$ Anthony 2007, 321-22, 440.
} 
TABLE 1. The Germanic lexicon divided into a regular Proto-Indo-European part and an irregular non-Indo-European part according to the formal match or mismatch with corresponding words in Slavic, Latin, Greek, and Sanskrit.

\begin{tabular}{|c|c|c|c|c|c|}
\hline Proto-Indo-European & Germanic & Slavic & Latin & Greek & Sanskrit \\
\hline Axle: ${ }^{*} \mathrm{~h}_{2}$ eks- & OE eax & $o s b$ & axis & $a ́ k s o ̄ n$ & $a ́ k s ̣ a-$ \\
\hline Horse: ${ }^{*} \mathrm{~h}_{1}$ ekuo- & OS ehu- & - & equus & híppos & áśva- \\
\hline Sheep: ${ }^{*} h_{3}$ eui- & OS ewi & - & ovis & óis & ávi- \\
\hline Wheel $1:{ }^{*} k^{\mathrm{w}} \mathrm{ek}^{\mathrm{w}}$ lo- & OE hwēol & - & - & kúklos & cakrá- \\
\hline Wheel 2: *HrotHo- & OHG rat & - & rota & - & rathá- ${ }^{\mathrm{a}}$ \\
\hline Wool: ${ }^{*} \mathrm{~h}_{2} \mathrm{ulh}_{1}-\mathrm{n}-$ & OE wull & $v b \ln a$ & lāna & lẽ̃nos & úrṇā- \\
\hline Yoke: *iug-o- & Go.juk & jogo & iugum & zugón & yugá- \\
\hline Non-Indo-European & Germanic & Slavic & Latin & Greek & Sanskrit \\
\hline Bean: ${ }^{*} b^{h_{a}}{ }^{-}{ }^{*} b^{h_{a}} b^{h_{-} b}$ & ON baun & bobr & $f a b a$ & - & - \\
\hline Cereal: ${ }^{*} b^{h}$ ares- $\sim^{*} b^{h}$ ars- & Go.bariz-c & boršbno ${ }^{\mathrm{d}}$ & $f a r^{\mathrm{e}}$ & - & - \\
\hline Flax: ${ }^{*} \operatorname{lin}-\sim{ }^{*} \operatorname{lin}-$ & Go. lein ${ }^{\mathrm{f}}$ & lonz & linum & línon & - \\
\hline Lentil: ${ }^{*} \operatorname{lnt}-\sim{ }^{*} \ln d^{\mathrm{h}}-$ & OHG linsi ${ }^{\mathrm{f}}$ & lętja $a^{\mathrm{f}}$ & lēns, -tis & láthyros ${ }^{\mathrm{g}}$ & - \\
\hline $\begin{array}{l}\text { Pea, chickpea: }{ }^{*} \text { orw- } \sim^{*} \text { erw- } \\
{ }^{*} \text { ereb- }{ }^{*} \text { orob- }\end{array}$ & OS erwit & - & ervum ${ }^{\mathrm{h}}$ & $\begin{array}{l}\text { erébinthos; } \\
\text { órobos }\end{array}$ & - \\
\hline Turnip: *rāp- *rap- & OHG ruoba & rěpa $a^{\mathrm{i}}$ & rāpa & rháp(h)us & - \\
\hline
\end{tabular}

Go. = Gothic; OE = Old English; OHG = Old High German; ON = Old Norse; OS = Old Saxon

Note: While terms associated with animal husbandry, wool production, and wagon technology fall into the regular layer of inherited Indo-European vocabulary, most names for old food crops cluster in the irregular part of the lexicon, which consists of prehistoric loanwords. These loanwords lack correspondences in the Asian branches, such as Sanskrit, which suggests that they entered the individual Indo-European daughter languages in Europe.

${ }^{a}$ Meaning "wagon."

${ }^{\mathrm{b}}$ A corresponding word is extant in the unrelated Berber languages; cf. Figuig baw "bean."

cMeaning "barley."

dMeaning "flour."

e Meaning "spelt" in the singular and "grain" in the plural.

${ }^{\mathrm{f}}$ Possibly borrowed from Latin.

${ }^{g}$ Meaning "grass pea, chickling pea."

h Meaning "bitter vetch."

${ }^{\mathrm{i}}$ With unclear vowel; cf. Lithuanian rópe "turnip" < Proto-Balto-Slavic *rāpiā-.

with agriculture, as has been previously claimed, ${ }^{17}$ is therefore problematic.

\section{NON-INDO-EUROPEAN LOANWORDS IN PROTO- GERMANIC}

Though Europe's first farmers probably did not speak Proto-Indo-European, their language may have

\footnotetext{
${ }^{17}$ Renfrew 1987; Gray and Atkinson 2003; Heggarty 2014, 2015. Contra, e.g., Sherratt and Sherratt 1988, 586; Kallio 2003, 234.
}

left traces within the Indo-European languages of Europe. The picture of the Indo-European parent language has become increasingly clear thanks to increasing precision in reconstruction. A problem that has been lingering in the dark since the beginning of Indo-European linguistics, however, is that, despite a long tradition of etymological research, numerous components of the Indo-European languages' vocabularies cannot be traced back to the Indo-European parent. For example, it has therefore been suspected ever since the discovery of the Indo-European language family that Germanic was "blended with a very 
different idiom." ${ }^{18}$ Germanic, in other words, may have emerged out of a process whereby speakers of an Indo-European dialect absorbed "populations speaking non-Indo-European languages into the newly formed speech communities." 19 Whether "[ $t]$ he process of Indo-Europeanization ... must be understood as a military victory in terms of successfully imposing a new administrative system, language, and religion on the indigenous groups" ${ }^{\prime 20}$ is a matter of speculation, but the fact is that, though the Indo-European dialect that ultimately evolved into Germanic became the dominant language in southern Scandinavia, it is extremely improbable that it was not influenced at all by the linguistic groups that previously covered the area.

The question thus arises whether we can make a linguistic statement about the nature and origin of those languages despite the fact that they went extinct long before the beginning of the historical record. There is, in fact, a linguistic technique that allows us to do so. ${ }^{21}$ Historical linguists have reached a comprehensive understanding of, first, what sounds could occur in ProtoIndo-European words and, second, how these sounds evolved in the daughter languages. But, while words inherited from the parent language generally conform to the established sound changes, both modern and prehistoric loanwords typically disrupt the matrix of regular sound correspondences and can thus be detected even when the source language is lost. By systematically applying this technique to the Germanic lexicon, and particularly to those words that do not have cognates in the non-European branches Anatolian, Tocharian, and Indo-Iranian, some general conclusions can be drawn about the linguistic and cultural landscape that existed in Europe prior to the arrival of the Indo-Europeans. One of the striking features of the lexical layer surviving from this landscape is that it contains a cluster of words belonging to the sphere of agriculture (see table 1).

On the basis of this clustering, it seems safe to claim that the language that donated the words for crops to the Indo-European dialect that later developed into Germanic was spoken by a culture whose subsistence strategy was more pervasively agricultural than that of

\footnotetext{
${ }^{18}$ Jones 1788; Roberge 2010, 407; Kroonen 2012b, 240.

${ }^{19}$ Polomé 1989, 54.

${ }^{20}$ Rifkin 2007, 57.

${ }^{21}$ For the methodology, cf. Polomé 1989; Markey and Greppin 1990; Schrijver 1997; Andersen 2003; Bammesberger and Vennemann 2003; Mees 2003; Roberge 2010.
}

the predominantly pastoral Indo-Europeans. When Indo-European speakers encountered farmers living in southern Scandinavia, the latter were apparently familiar with a more well-developed crop assemblage. Words related to farming practices as well as other local terminology were therefore naturally adopted by the Indo-European dialect that later surfaced as the Germanic subgroup. ${ }^{22}$ The hypothesis that we therefore entertain here is that the donor language, which went extinct long before the beginning of the historical record but apparently not before the introduction of Indo-European speech, was the language of Scandinavia's first farmers. ${ }^{23}$

Additional evidence that this Neolithic language was introduced by farming pioneers migrating in a southnorth direction can be collected from the other IndoEuropean dialects in Europe-that is, Balto-Slavic, Italo-Celtic, Armenian, and Greek. Like Germanic, these dialects can also be shown to contain non-European lexical layers. Though much work still remains to be done, these layers contain lexical material carrying a Neolithic signature comparable to that found in Germanic. This signature primarily consists of the same non-Indo-European words occurring across the Indo-European dialects of Europe, but there is also accumulating evidence for the prevalence of recurrent non-Indo-European derivational patterns. The nonIndo-European words outlined in table 2 all exhibit the same alternation consisting of forms with and without word-initial $a$-. In all likelihood, this was a productive derivational element-that is, a prefix-in the language from which these words were borrowed. ${ }^{24}$

Though recurrent patterns such as these do not (yet) allow us to establish an exact genetic affiliation of the language that served as the donor of these words, they provide evidence that Europe prior to its Indo-Europeanization was at least partially covered by a linguistically uniform continuum that consisted of a language or group of related languages stretching from the Mediterranean in the south to Scandinavia in the north (fig. 5). The existence of this continuum is based on three primary considerations: (1) a large geographic distribution of this Neolithic layer; (2) a clustering of agricultural terms; (3) a close archaeological window for contact between farmers and IndoEuropean speakers in Denmark. The continuum thus

\footnotetext{
${ }^{22}$ Kroonen 2012a, 2012b.

${ }^{23}$ Kallio 2003, 233; Schrijver 2011; Kroonen 2012a, 2012 b.

${ }^{24}$ Schrijver 1997.
} 
TABLE 2. Evidence for the non-Indo-European $a$-prefix.

\begin{tabular}{|c|c|c|}
\hline Non-Indo-European Original & Borrowed Unprefixed Form & Borrowed $a$-Prefixed Form \\
\hline Aquatic bird: *rod $\sim^{*}$ a-rd & $\begin{array}{l}\text { Gr. (e)rōdiós "heron" < *rōd-; SCr. } \\
\text { róda "stork" < "rod" }\end{array}$ & ON arta "teal, garganey" < *a-rd- \\
\hline Blackbird: *mesl *a-msl & Lat. merula $<{ }^{*}$ mesl- & OHG amsala <*a-msl- \\
\hline Crustacean: *re?k *a-r?k & $\begin{array}{l}\text { ON rcekja "shrimp"; Icel. rá } \\
\text { "amphipod"<*re?k- }\end{array}$ & $\begin{array}{l}\text { Ru. rak"crayfish"; Lith. érkè "tick, } \\
\text { mite" < *a-r?k- }\end{array}$ \\
\hline Garlic: *gedl *a-gdl & Gr. gélgis < * gedl- & Gr. áglis, Lat. allium < *a-gdl- \\
\hline Lark: *laiwað *a-lauð & OE lāwerce < *laiwar- & Gall. alauda < *a-laud- \\
\hline Nut, walnut: *rai?s *a-r?s(?) & Lith. ríešas, riešutas < ${ }^{*}$ rai?s- & $\begin{array}{l}\text { Ru. oréx }<* \text { a-rai?s-; Alb. arrë }< \\
\text { *a-r?s-(?) }\end{array}$ \\
\hline Ore: ${ }^{*}$ raud $\sim$ *a-rud & Lat. raudus $<$ *raud- & OHG aruz $<*$ a-rud- \\
\hline Sedge: ${ }^{*}$ sak / ${ }^{*}$ se-sk $\sim{ }^{*} \mathrm{a}-\mathrm{s}(\mathrm{a}) \mathrm{k}$ & $\begin{array}{l}\text { OE secge <* sak-; OIr. seisc < * se-sk- } \\
\text { (cf. Ba. seska) }\end{array}$ & Ru. osóka <*a-sak- \\
\hline Sturgeon: ${ }^{*} \operatorname{setr} \sim{ }^{*} \mathrm{a}-\mathrm{s}(\mathrm{e}) \operatorname{tr}$ & OHG sturio < *str- & Ru. osëtr <*a-setr- \\
\hline Turnip: *rap *a-rb & $\begin{array}{l}\text { Gr. rháp }(h) \text { us < *rap-; Lat. rāpa, } \\
\text { OHG ruoba }<\text { *rāp- }\end{array}$ & $\mathrm{W}$ erfin $<{ }^{*} \mathrm{a}-\mathrm{rb}^{(\mathrm{h})}-(\mathrm{cf} . \mathrm{Ba} \cdot \operatorname{arbi})$ \\
\hline Wriggly animal: ${ }^{*}$ sker $\sim{ }^{*}$ a-skr & $\begin{array}{l}\text { OHG skero "mole" <*sker- (cf. Ba. } \\
\text { mari-skira "shrimp"?) }\end{array}$ & $\begin{array}{l}\text { Gr. áskaris "worm" <*a-skr-; Ru. } \\
\text { jáščer "lizard" < *a-sker- }\end{array}$ \\
\hline
\end{tabular}

Alb. = Albanian; Ba. = Basque; Gall. = Gallo-Latin; Gr. = Greek; Icel. = Icelandic; Lat. = Latin; Lith. = Lithuanian; OE = Old English; OHG = Old High German; OIr. = Old Irish; ON = Old Norse; Ru. = Russian; SCr. = Serbian \& Croatian; W = Welsh

Note: Examples taken from Schrijver 1997, 307-12; Kroonen 2012a; 2012b; 2013, 36, 415, 421, 488; Derksen 2014, 382, 402-3. The a-prefix is found in prehistoric loanwords adopted by the Indo-European branches in Europe-e.g., Greek, Latin, Celtic, Germanic, and Balto-Slavic. The consistency of the pattern, with loanwords alternating between prefixed and unprefixed forms, suggests that these branches were in contact with a single, non-Indo-European language or language group in which this prefix was a productive morphological or derivational element.

potentially matches the spread of agriculture from the eastern Mediterranean to Scandinavia between the eighth and fourth millennia B.C.E. The linguistic evidence, in other words, supports recent findings from archaeogenetics that the Neolithization process was indeed coupled not only with the influx of new ideas and genes but also with the introduction of a specific language. This language, however, was not Proto-IndoEuropean; it was rather an unknown, entirely unrelated language, here referred to as Early European Neolithic.

\section{CULTURAL AND LINGUISTIC DIVERSITY IN LATER NEOLITHIC SOUTHERN SCANDINAVIA}

From the linguistic evidence presented above we have learned (1) the first farming communities in northern Europe probably spoke a non-Indo-European language; (2) this Early European Neolithic language contained a layer of agricultural vocabulary that was shared with other early Neolithic communities across Europe; (3) the language may have spread across Europe together with Neolithic life, which besides economic aspects such as agriculture, animal husbandry, and pastoralism included shared technologies such as pottery making and the use of polished flint and stone tools; and (4) Proto-Indo-European, the ancestor of Pre-Germanic, was introduced at a time when the Early European Neolithic language was still in use.

How can these linguistic facts be matched with the archaeological evidence? If we are to explain the adoption of old agricultural words originating in a lost Neolithic language by an Indo-European dialect, we must expect a certain chronological overlap between the speakers of these two languages. Many linguistic specialists agree that Proto-Indo-European arose during the period ca. 4500-3500 B.C.E., after which it started breaking up and finally dissolved ca. 
2500 B.C.E. ${ }^{25}$ What we are therefore looking for is a period within the maximum time span of ca. 45002500 B.C.E. in which the cultural milieu allowed for the adoption of old agricultural words into the future European branches of the Indo-European language family, particularly Germanic. One scenario could be that the intermixture of agricultural words into Proto-Indo-European happened during the formation process of the earliest Corded Ware societies. The Corded Ware phenomenon probably developed from late southeast Polish Funnel Beaker and neighboring populations, including migrating Yamnaya groups, as strongly indicated by recent ancient DNA (aDNA) studies. These studies show substantial genetic influx from the Pontic-Caspian steppe into eastern-central Europe at the very beginning of the third millennium B.C.E., at the time when early Corded Ware groups evolved. Thus it is very likely that migrating Yamnaya people played a key role in the formation of the Corded Ware phenomenon. ${ }^{26}$ Though some of the agricultural words may have been adopted in this process, we think the archaeological record of early third-millennium B.C.E. Scandinavia provides a particularly apt setting for the given linguistic scenario. The beginning of the Neolithic in Scandinavia is defined by the presence of domesticated crops and the occurrence of the Funnel Beaker culture ca. 4000 B.C.E. (cf. figs. 1, 2). This remained the sole archaeological culture throughout the fourth millennium B.C.E. From ca. 3000 B.C.E., we see significant changes in the material culture, including new types of pottery, battle-axes, and arrowheads, as well as changes in settlement patterns, subsistence economic practices, and burial customs. These changes are generally related to the appearance of new Middle Neolithic "cultures" including the Pitted Ware culture, the Single Grave culture (cf. fig. 3), and the Swedish-Norwegian BattleAxe culture. The two last-mentioned groups belong to the larger Corded Ware complex, which is widely regarded as a likely vector of Indo-European speech. ${ }^{27}$ Thus, it is tempting to see the introduction of IndoEuropean as a part of the material and cultural changes associated with the rise of the Single Grave culture in

\footnotetext{
${ }^{25}$ Mallory 1989, 158-59; Whittle 1996, 137-38; Anthony 2007, 58-9.

${ }^{26}$ Anthony 2007, 367-68; Allentoft et al. 2015; Haak et al. 2015; Goldberg et al. 2017,7 March; Kristiansen et al. 2017.

${ }^{27}$ Gimbutas 1965; Mallory 1989, 108-9; Kristiansen 1991; Anthony 2007; Sjögren et al. 2016.
}

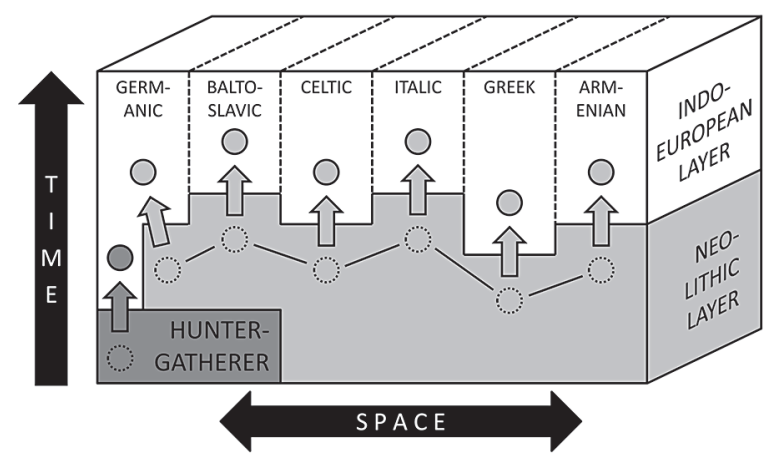

FIG. 5. Schematic impression of how the different Indo-European branches may have absorbed lexical items (circles) from previously spoken languages in the linguistically complex setting of Europe from the third millennium B.C.E. The borrowing of lexical items from hunter-gatherers into Germanic refers to the potential adoption of Proto-Germanic * selhaz "seal" (Old Norse selr, Old English seolh, Old High German selah) as well as Early Proto-Balto-Finnic *süllkeš "seal” (Finnish hylje, Estonian hüljes) from the marine-oriented Sub-Neolithic Pitted Ware culture.

an area that was previously dominated by the Funnel Beaker culture.

\section{THE SINGLE GRAVE CULTURE}

The emergence of Corded Ware communities in southern Scandinavia started ca. 2850 B.C.E. and covered a restricted area of the central and western Jutland Peninsula (fig. 6). From the very beginning we see a fully developed Corded Ware idiom with interments of east-west oriented, flexed individuals covered by small burial mounds and accompanied by curved (also termed "S-profiled") cord-decorated beakers and new types of stone battle-axes as well as amber ornaments (see fig. 3).

Unfortunately, very few graves contain preserved human bones suitable for isotopic or aDNA analyses that could help decide whether the buried individuals were migrants, as advocated by Glob and Kristiansen, ${ }^{28}$ or rather indigenous Funnel Beaker people who had adopted a new culture and ideology. ${ }^{29}$ Only the contours of the body are preserved in the sandy limedeficient soils of central and western Jutland.

However, detailed studies of two superimposed early Single Grave culture burials from Refshøjgård,

\footnotetext{
${ }^{28}$ Glob 1945, 241-58; 1971, 106-8; Kristiansen 1991, 2009, 2012.

${ }^{29}$ Damm 1993; Hübner 2005, 694-719.
} 


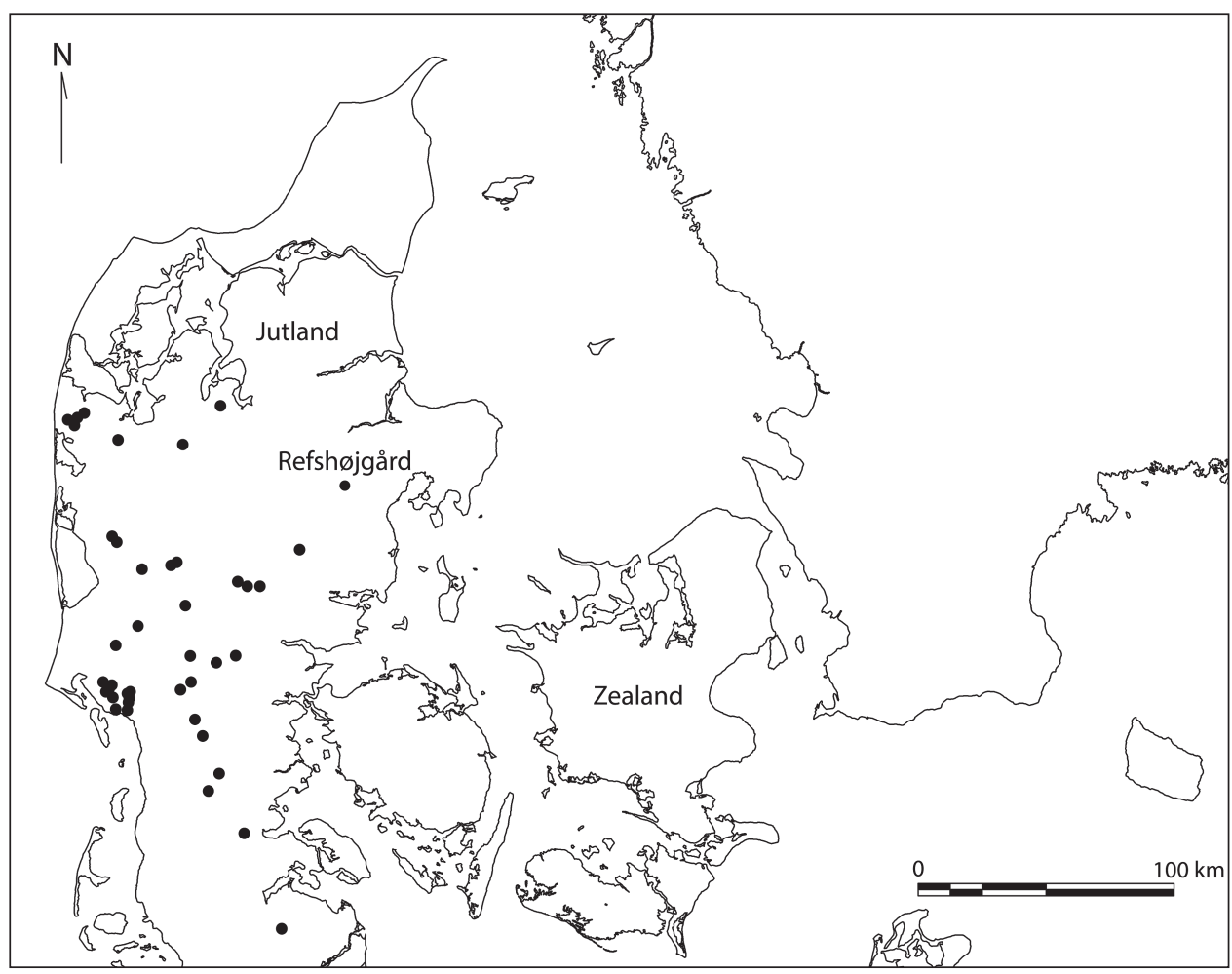

FIG. 6. Distribution of the earliest Single Grave culture burials in southern Scandinavia, ca. 2850-2800 B.C.E. The data are taken from Hübner 2005, fig. 470; Klassen 2005, fig. 1.

eastern Jutland, show Funnel Beaker elements mixed with Single Grave elements, including a Corded Ware beaker imitating those found in the area just south of the Harz in central Germany. ${ }^{30}$ The local Funnel Beaker traits include traces of the common practice of depositing broken pottery in connection with burials (in this case, pottery sherds were found in the mound filling and have been interpreted as deliberately deposited during the construction of the burial mound), ${ }^{31}$ a flint axe showing typological Funnel Beaker traits, and the geographic location of the burial mound itself. The two graves are typical Single Grave culture burials covered by a burial mound, but the location of the mound outside the early Single Grave core area in a region otherwise rich in Funnel Beaker sites contributes to the significance of the find. The Refshøjgård burials suggest that the occurrence of the Single Grave culture on the Jutland Peninsula should be explained as a combination of local Funnel Beaker developments, geographi-

\footnotetext{
${ }^{30}$ Klassen 2005.

${ }^{31}$ Klassen 2005, 32-3, 45.
}

cally distant contacts, and small-scale migrations such as translocation of individuals or small groups.

Other studies of the Single Grave culture have also noted that certain stylistic pottery elements and other features deriving from central Germany can be found within the early Single Grave milieu on the Jutland Peninsula. ${ }^{32}$ Thus, it is very likely that the Harz area held a significant role in transmitting early Corded Ware influences, as proposed by Klassen. ${ }^{33}$ These influences probably originated in southeastern Poland or adjacent areas farther to the southeast, regions that have produced the earliest radiocarbon dates, ca. $3000-2900$ B.C.E. ${ }^{34}$

\section{CULTURAL HETEROGENEITY AND THE CHANCE OF MUTUAL LANGUAGE INFLUENCES}

At the time the Single Grave communities began, southern Scandinavia was occupied by the late Funnel

\footnotetext{
${ }^{32}$ Hvass 1992, 221-22; Zich 1993, 28; Hübner 2005, 739, 743, 754; Ebbesen 2006, 187-92.

${ }^{33}$ Klassen 2005, 45-6.

${ }^{34}$ Furholt 2003, 21-2, 32, 118-23.
} 
Beaker culture. From radiocarbon dates and stratigraphic observations of early Single Grave burial mounds overlying final phase Funnel Beaker settlements, we know that the Single Grave culture succeeded the Funnel Beaker culture in central and western Jutland ca. $2850 / 2800$ B.C.E. ${ }^{35}$

However, a revision of old and new radiocarbon dates from eastern Denmark (including eastern Jutland) shows that the final Funnel Beaker phase was rather long-lived, lasting until ca. 2600 B.C.E. ${ }^{36}$ From this late date onward in eastern Denmark, we see influences in the form of battle-axes and beakers of the Single Grave type. Still, these elements are very few compared with the number in central and western Jutland. ${ }^{37}$ Battle-axes of the Single Grave type were introduced at the expense of old Funnel Beaker types, but no increase in the number of axes can be detected as was the case in central and western Jutland, where battle-axes were part of male burials and the number increased by several hundred percent with the occurrence of the Single Grave culture. ${ }^{38}$

Furthermore, it is clear that differences in burial practice separated communities living in eastern and western Denmark. While the characteristic Single Grave burials number close to 2,400 in central and western Jutland, ${ }^{39}$ reuse of megalithic tombs remained the predominant way of burying people in eastern Denmark. Fewer than 10 single graves have been detected on Zealand and adjacent islands. ${ }^{40}$ What we see is a "cultural creolization process" in which people selectively adopted, transformed, and used new Single Grave material elements in accordance with the underlying cultural norms of the Funnel Beaker culture. ${ }^{41}$

The continued low frequency of stone battle-axes, the almost total rejection of the individual burials of the Single Grave culture, the continued deposition of flint axes/adzes, and the reuse of megalithic tombs clearly show the continuation of old Funnel Beaker norms even after the end of the Funnel Beaker culture ca. 2600 B.C.E. Not only was the "Funnel Beaker way" actively upheld by the reuse of megalithic tombs, it

\footnotetext{
${ }^{35}$ Hübner 2005, 667-68.

${ }^{36}$ Iversen 2015 , esp. ch. 3.

${ }^{37}$ Iversen 2016.

${ }^{38}$ Iversen 2015.

${ }^{39}$ Hübner 2005, 60.

${ }^{40}$ Iversen 2013, 23, fig. 3.

${ }^{41}$ Iversen 2015.
}

probably also constituted the underlying sociostructural backbone of the final Middle Neolithic postFunnel Beaker societies of eastern Denmark. The old Funnel Beaker norms governed the adoption and rejection of material culture elements, including types of objects, the restricted use of battle-axes, mortuary and depositional practices, and contact networks.

Together with this cultural fusion process we might also include linguistic interaction resulting in the borrowing between two languages derived from Early European Neolithic and Proto-Indo-European. As we have argued elsewhere, Corded Ware generally offers favorable cultural contexts for linguistic contact between migrant Indo-European pastoralists and indigenous Neolithic groups, ${ }^{42}$ but the cultural situation in southern Scandinavia was particularly well-suited for agricultural and other loanwords to be adopted by the Indo-European dialect that ultimately developed into Proto-Germanic. In the more than 250 years (ca. 2850-2600 B.C.E.) when late Funnel Beaker farmers coexisted with the new Single Grave culture communities within a relatively small area of present-day Denmark, processes of cultural and linguistic exchange were almost inevitable - if not widespread.

Despite influences from the Single Grave culture on the societies of eastern Denmark, the Funnel Beaker tradition remained strong in the latter area. The geographic division between central/western Jutland and the east Danish islands formed a cultural border between two ideologies and social structures. The late Funnel Beaker societies were probably organized in kinship-based tribal or clan communities headed by some sort of leading figures and ritual specialists managing the complicated funeral rituals, including the use of megalithic tombs, and hosting great gatherings at causewayed and palisaded enclosures. The relatively few battle-axes that were in circulation within the Funnel Beaker culture were reserved for such tribal leaders. ${ }^{43}$

A somewhat different form of social structure was in practice for the Jutland Single Grave communities. Tribal, kinship-based organization was probably a structuring principle, but the significance of the group was downscaled in relation to the importance of individual family units headed by a male member. Such

\footnotetext{
${ }^{42}$ Kristiansen et al. 2017.

${ }^{43}$ Iversen 2015, esp. ch. 7.
} 
males are found in the single graves, and they probably belonged to groups or "brotherhoods" of battle-axecarrying males. These brotherhoods apparently had no clearly formalized hierarchization, and their members were probably more or less equal. ${ }^{44}$ In general, a certain warrior identity seems to have developed in the later European Neolithic and to have become a central element of the Bronze Age male ideal. ${ }^{45}$

The geographic division between the Single Grave and Funnel Beaker areas followed the natural landscape as shaped by the latest glacial period. The old morainic unglaciated area of central and southwestern Jutland was left as sandy outwash plains with relatively poor soils, whereas most of the remaining and glaciated Denmark (the young moraine area) comprised fertile clayish soils. These natural conditions also created opportunities for different types of subsistence economies.

Thus from ca. 2800-2600 B.C.E. onward we are dealing with two clearly distinct ecozones and landuse strategies in southern Scandinavia that correspond with two different material culture expressions: the Single Grave culture and the late Funnel Beaker culture. The cultural division of southern Scandinavia formed a rather persistent border that lasted until the emergence of the classical Nordic Bronze Age, beginning with Period II (ca. 1500 B.C.E.). During the Late Neolithic and earliest Bronze Age (ca. 2350-1500 B.C.E.), the division is seen in different contact networks and the use of different dagger types, burial customs, regionalized metalwork, and a differentiated introduction of the three-aisled longhouse. ${ }^{46}$

If we are to believe that persistent cultural borders mirror language borders, ${ }^{47}$ the introduction of an IndoEuropean dialect-and its subsequent development into Pre-Proto-Germanic during the centuries to follow - might have been a long process lasting from the emergence of Single Grave communities to the development of the culturally homogeneous classical Nordic Bronze Age, running ca. 2850 B.C.E. to ca. 1500 B.C.E. Within this approximately 1,350 -year period, people may have spoken two different languages, with Pre-Proto-Germanic gradually becoming dominant.

\footnotetext{
${ }^{44}$ Vandkilde 2007, 68-71, 79-87; 2011.

${ }^{45}$ Treherne 1995; Kristiansen et al. 2017.

${ }^{46}$ Lomborg 1973; Vandkilde 1996, 287-94; Kristiansen and Larsson 2005, 118-32; Kristiansen 2009.

${ }^{47}$ Anthony 2007, 104-8; Kristiansen 2009, 116.
}

In this type of culturally and presumably linguistically mixed setting, it is almost inevitable that lexical items, particularly words for agriculture and local flora and fauna, were transferred from a local Early European Neolithic language into the intrusive Indo-European dialect that later surfaced as Germanic.

This situation can perhaps be compared to the prolonged coexistence of Greeks and Minoans in the southern Aegean. Minoan was the language of the Cretan Hieroglyphic and Linear A scripts in use ca. 2000-1500 B.C.E. With the arrival of the Hellenic Mycenaeans, Minoan civilization collapsed, and, from ca. 1450 B.C.E. onward, Minoan writing traditions were superseded by the Greek-based Linear B. Nevertheless, isolated pockets of Minoan speech may have lingered on for more than a millennium before finally going extinct, only temporarily resurfacing in the equally non-Greek Eteocretan inscriptions between the sixth and third centuries B.C.E. During this long period of potential cultural and linguistic interaction, there was a significant influx of non-Indo-European words into Greek. $^{48}$

However, influences from the Single Grave culture and the "Corded Ware world" can be seen from the spread of battle-axes and beakers of the Single Grave type to eastern Denmark, mainly occurring after the Funnel Beaker culture had ended ca. 2600 B.C.E. Thus, we might expect not only a cultural creolization process in eastern Denmark but also a process of linguistic hybridization facilitating their cultural intertwinement, in particular from 2600 B.C.E. onward. Single Grave individuals would have borrowed numerous local terms from the Early European Neolithic language, which itself came to serve as a linguistic substrate, transferring numerous of its features back into the Corded Ware superstrate as its speakers gradually shifted to a form of Indo-European. The result of this long-term process ultimately resulted in the dominance of Pre-ProtoGermanic and the extinction of the local Early European Neolithic language, but not before a detectable amount of culturally significant vocabulary was transferred from one language to the other.

\section{CONCLUSIONS}

Based on linguistic and archaeological evidence, we have attempted to create a unified scenario for how and when Indo-European was implemented in southern

\footnotetext{
${ }^{48}$ Renfrew 1998; Beekes 2014.
} 
Scandinavia. The archaeological situation in the third millennium B.C.E. testifies to considerable cultural diversity. Corded Ware/Single Grave communities appear on the Jutland Peninsula ca. 2850 B.C.E., but the subsistent late Funnel Beaker culture continued for several hundred years in the eastern parts of southern Scandinavia together with Sub-Neolithic Pitted Ware groups. It was not until the onset of the classical Nordic Bronze Age ca. 1500 B.C.E. that the otherwise persistent sociocultural border between the western and eastern parts of southern Scandinavia was erased.

The reconstructed linguistic prehistory of southern Scandinavia closely mirrors the known archaeological record. Indo-European speech was most likely introduced along with the Corded Ware influences. Germanic evolved out of the Indo-European dialect that was introduced at the time, but not without being influenced by an unknown Early European Neolithic language spoken by the descendants of Europe's earliest agriculturalists. While the Corded Ware area offers a plausible context for linguistic contact between IndoEuropean-speaking pastoralists and local Neolithic farmers in general, ${ }^{49}$ the sustained cultural diversity that characterized southern Scandinavia in the early third millennium B.C.E. provides an especially propitious setting for the transfer of agricultural and other terminology from a Neolithic language to an early form of Pre-Proto-Germanic.

Needless to say, our findings have an important bearing on the debate about the Indo-European homeland. Since the linguistic facts suggest that speakers of IndoEuropean encountered deeply agrarian populations when they arrived in Europe, they cannot themselves have been Europe's earliest farmers. Instead, the IndoEuropean speakers arrived with the wagon technology and animal husbandry characteristic of the pastoralists of the Pontic-Caspian steppe. The archaeological record of southern Scandinavia provides just the right cultural and geographic setting for the proposed linguistic contact between non-Indo-European-speaking agrarian groups and incoming speakers of Indo-European in the early third millennium B.C.E. As a result, the combined linguistic and archaeological evidence clearly favors the steppe hypothesis over the Anatolian hypothesis on the origin of the Indo-European language family.

\footnotetext{
${ }^{49}$ Kristiansen et al. 2017.
}

Rune Iversen

University of Copenhagen

SAXO Institute, Department of Archaeology

Karen Blixens Plads 8

2300 Copenhagen $S$

Denmark

runeiversen@hum.ku.dk

Guus Kroonen

University of Copenhagen

Institute for Nordic Studies and Linguistics

Emil Holmskanal 2

2300 Copenhagen $S$

Denmark

guus@hum.ku.dk

\section{Works Cited}

Alinei, M. 2000. "An Alternative Model for the Origins of European Peoples and Languages: The Continuity Theory." Quaderni di Semantica 21:21-50.

Allentoft, M.E. et al. 2015. "Population Genomics of Bronze Age Eurasia.” Nature 522(7555):167-72.

Andersen, H., ed. 2003. Language Contacts in Prehistory. Amsterdam: Benjamins.

Anthony, D.W. 2007. The Horse, the Wheel, and Language: How Bronze-Age Riders from the Eurasian Steppes Shaped the Modern World. Princeton: Princeton University Press.

Bammesberger, A., and T. Vennemann. 2003. Languages in Prehistoric Europe. Heidelberg: Winter.

Beekes, R.S.P. 2014. Pre-Greek, Phonology, Morphology, Lexicon. Brill: Leiden.

Beekes, R.S.P., and M. de Vaan. 2011. Comparative IndoEuropean Linguistics: An Introduction. Amsterdam and Philadelphia: John Benjamins.

Bellwood, P. 2005. First Farmers: The Origins of Agricultural Societies. Malden, Mass.: Blackwell.

2011. First Migrants: Ancient Migration in Global Perspective. Malden, Mass.: Blackwell.

Bouckaert, R., P. Lemey, M. Dunn, S.J. Greenhill, A.V. Alekseyenko, A.J. Drummond, R.D. Gray, M.A. Suchard, and Q.D. Atkinson. 2012. "Mapping the Origins and Expansion of the Indo-European Language Family." Science 337:957-60.

Clackson, J. 2007. Indo-European Linguistics: An Introduction. Cambridge: Cambridge University Press.

Damm, C. 1993. "The Danish Single Grave Culture-Ethnic Migration or Social Construct?" Journal of Danish Archaeology 10:199-204.

Demoule, J.-P. 2014. Mais où sont passés les Indo-Européens? Le mythe d'origine de l'Occident. Paris: Seuil.

Derksen, R. 2014. Etymological Dictionary of the Baltic Inherited Lexicon. Leiden: Brill.

Diamond, J., and P. Bellwood. 2003. "Farmers and Their Languages: The First Expansions.” Science 300:597-603.

Dugan, F.M. 2016, 20 December. "Multidisciplinary Contributions to Legume Crop History: Proceed with Caution.” 
Frontiers in Plant Science 7:1876. http://journal.frontiersin. org/article/10.3389/fpls.2016.01876/full.

Ebbesen, K. 2006. The Battle Axe Period. Copenhagen: Attika. - 2009. The Origins of the Indo-European Languages/ De indoeuropeiske sprogs oprindelse. Copenhagen: Attika.

Fort, J. 2012. "Synthesis Between Demic and Cultural Diffusion in the Neolithic Transition in Europe." Proceedings of the National Academy of Sciences 109(46):18669-73.

Fortson, B.W. 2010. Indo-European Language and Culture: An Introduction. 2nd ed. Chichester, England: Wiley-Blackwell.

Furholt, M. 2003. Die absolutchronologische Datierung der Schnurkeramik in Mitteleuropa und Südskandinavien. Universitätsforschungen zur prähistorischen Archäologie 101. Bonn: Rudolf Habelt.

Gamkrelidze, T.V., and V. Ivanov. 1995. Indo-European and the Indo-Europeans: A Reconstruction and Historical Analysis of a Proto-Language and a Proto-Culture. Vol. 2. Berlin and New York: Mouton.

Gimbutas, M. 1956. The Prehistory of Eastern Europe. Pt. 1, Mesolithic, Neolithic and Copper Age Cultures in Russia and the Baltic Area. Cambridge, Mass.: Peabody Museum. 1965. Bronze Age Cultures in Central and Eastern Europe. The Hague and London: Mouton.

Glob, P.V. 1945. "Studier over den jyske enkeltgravskultur." Aarbøger for nordisk Oldkyndighed og Historie 1944:1-283.

- 1971. Denmark: An Archaeological History from the Stone Age to the Vikings. New York: Cornell University Press.

Goldberg, A., T. Günther, N.A. Rosenberg, and M. Jakobsson. 2017, 7 March. "Ancient X Chromosomes Reveal Contrasting Sex Bias in Neolithic and Bronze Age Eurasian Migrations." Proceedings of the National Academy of Sciences 114(10):2657-62.

Gray, R.D., and Q.D. Atkinson. 2003. "Language-Tree Divergence Times Support the Anatolian Theory of IndoEuropean Origin.” Nature 426(6965):435-39.

Haak, W. et al. 2010, 9 November. "Ancient DNA from European Early Neolithic Farmers Reveals Their Near Eastern Affinities." PLOS Biology 8(11):e1000536. https:// doi.org/10.1371/journal.pbio.1000536.

Haak, W. et al. 2015. "Massive Migration from the Steppe Was a Source for Indo-European Languages in Europe." Nature 522(7555):207-11.

Heggarty, P. 2014. "Prehistory by Bayesian Phylogenetics? The State of the Art on Indo-European Origins." Antiquity 88(340):566-77.

2015. "Prehistory Through Language and Archaeology.” In Routledge Handbook of Historical Linguistics, edited by C. Bowern and B. Evans, 598-626. London: Routledge.

Hester, D.A. 1968. "Recent Developments in Mediterranean 'Substrate' Studies." Minos 9:219-35.

Hübner, E. 2005. Jungneolithische Gräber auf der Jütischen Halbinsel: Typologische und chronologische Studien zur Einzelgrabkultur. Nordiske Fortidsminder ser. B, vol. 24. Copenhagen: Det Kgl. Nordiske Oldskriftselskab.

Hvass, L. 1992. “Die Einzelgrabkultur in Jütland, Dänemark.” In Die kontinentaleuropäischen Gruppen der Kultur mit Schnurkeramik, edited by M. Buchvaldek and C. Strahm, 221-28. Praehistorica 19. Prague: Univerzita Karlova.

Iversen, R. 2013. "Beyond the Neolithic Transition—the
"de-Neolithisation" of South Scandinavia." In NW Europe in Transition: The Early Neolithic in Britain and South Sweden, edited by M. Larsson and J. Debert, 21-7. BAR-IS 2475. Oxford: Archaeopress.

- 2015. The Transformation of Neolithic Societies: An Eastern Danish Perspective on the 3rd Millennium BC. Jutland Archaeological Society Publications 88. Højbjerg, Denmark: Jutland Archaeological Society and Aarhus University Press.

- 2016. "Was There Ever a Single Grave Culture in East Denmark? Traditions and Transformations in the 3rd Millennium BC." In Transitional Landscapes? The 3rd Millennium BC in Europe, edited by M. Furholt, R. Grossmann, and M. Szmyt, 159-70. Universitätsforschungen zur prähistorischen Archäologie 292. Bonn: Rudolf Habelt.

Jones, W. 1788. "Third Anniversary Discourse: On the Hindus, Delivered 2d February, 1786." Asiatick Researches 1: 415-31.

Kallio, P. 2003. "Languages in the Prehistoric Baltic Sea Region." In Languages in Prehistoric Europe, edited by A. Bammesberger and T. Vennemann, 227-44. Heidelberg: Winter.

Klassen, L. 2005. "Refshøjgård: Et bemærkelsesværdigt gravfund fra enkeltgravskulturen.” Kuml 2005:17-59.

Kristiansen, K. 1991. "Prehistoric Migrations-The Case of the Single Grave and Corded Ware Cultures." Journal of Danish Archaeology 8(1989):211-25.

_.2009. "Proto-Indo-European Languages and Institutions - an Archaeological Approach." In Departurefrom the Homeland: Indo-Europeans and Archaeology, edited by M.V. Linden and K. Jones-Bley, 111-40. JIES Monograph 56. Washington, D.C.: Institute for the Study of Man.

-2012. "The Bronze Age Expansion of Indo-European Languages: An Archaeological Model.” In Becoming European: The Transformation of Third Millennium Northern and Western Europe, edited by C. Prescott and H. Glørstad, 165-81. Oxford: Oxbow.

Kristiansen, K., and T.B. Larsson. 2005. The Rise of Bronze Age Societies: Travels, Transmissions and Transformations. Cambridge: Cambridge University Press.

Kristiansen, K. et al. 2017. "Re-Theorising Mobility and the Formation of Culture and Language Among the Corded Ware Culture in Europe." Antiquity 91(356):334-47.

Kroonen, G. 2012a. "An Akkadian Loanword in Pre-Greek:

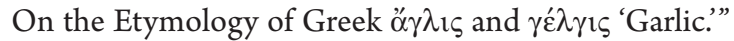
JIES 40(3-4):289-99.

- 2012b. "Non-Indo-European Root Nouns in Germanic: Evidence in Support of the Agricultural Substrate Hypothesis." In A Linguistic Map of Prehistoric Northern Europe, edited by R. Grünthal and P. Kallio, 239-60. Helsinki: Société Finno-Ougrienne.

- 2013. Etymological Dictionary of Proto-Germanic. Leiden and Boston: Brill.

Lomborg, E. 1973. Die Flintdolche Dänemarks: Studien über Chronologie und Kulturbeziehungen des südskandinavischen Spätneolithikums. Nordiske Fortidsminder ser. B, vol. 1. Copenhagen: Det Kgl. Nordiske Oldskriftselskab.

Mallory, J.P. 1989. In Search of the Indo-Europeans: Language, Archaeology and Myth. London: Thames \& Hudson. 
Mallory, J.P., and D.Q.Adams. 2006. The Oxford Introduction to Proto-Indo-European and the Proto-Indo-European World. Oxford: Oxford University Press.

Malmström, H. et al. 2009. "Ancient DNA Reveals Lack of Continuity Between Neolithic Hunter-Gatherers and Contemporary Scandinavians." Current Biology 19(20): 1758-62.

Markey, T.L., and J.A.C. Greppin. 1990. When Worlds Collide: The Indo-Europeans and Pre-Indo-Europeans, the Rockefeller Foundation's Bellagio Study and Conference Center, Lake Como, Italy, February 8-13, 1988. Ann Arbor, Mich.: Karoma Publishers.

Mees, B. 2003. "Stratum and Shadow: A Genealogy of Stratigraphy Theories from the Indo-European West.” In Language Contacts in Prehistory, edited by H. Andersen, 11-44. Amsterdam: Benjamins.

Mikić, A. 2012, 4 September. "Origin of the Words Denoting Some of the Most Ancient OldWorld Pulse Crops and Their Diversity in Modern European Languages." PLOS ONE 7(9):e44512. http://dx.doi.org/10.1371/journal.pone. 0044512.

Pokorny, J. 1959-1969. Indogermanisches etymologisches Wörterbuch. Bern: French \& European Publications.

Polomé, E.C. 1989. "Substrate Lexicon in Germanic." NorthWestern European Language Evolution 14:53-73.

Price, T.D. 2013. Europe Before Rome: A Site-by-Site Tour of the Stone, Bronze and Iron Ages. Oxford and New York: Oxford University Press.

Renfrew, C. 1987. Archaeology and Language: The Puzzle of Indo-European Origins. Cambridge: Cambridge University Press.

- 1998. "Word of Minos: The Minoan Contribution to Mycenaean Greek and the Linguistic Geography of the Bronze Age Aegean." CAJ 8(2):239-64.

Rifkin, M.J. 2007. "A Spatial Analysis of Neolithic Cultures Throughout Eastern, Central and Northern Europe in Relation to Proto-Germanic." JIES 35(1-2):53-81.

Roberge, P. 2010. "Contact and the History of Germanic Languages." In The Handbook of Language Contact, edited by R. Hickey, 407-31. Oxford: Wiley-Blackwell.

Schrijver, P. 1991. The Reflexes of the Proto-Indo-European Laryngeals in Latin. Amsterdam and Atlanta: Rodopi. . 1997. "Animal, Vegetable and Mineral: Some Western European Substratum Words." In Sound Law and Analogy, edited by A.M. Lubotsky, 293-316. Amsterdam and
Atlanta: Rodopi.

-2011. "La langue hattique et sa pertinence possible pour les contacts linguistiques préhistoriques en Europe occidentale." In Contacts linguistiques dans l'Occident méditerranéen antique, edited by C. Ruiz Darasse and E. Luján, 241-55. Madrid: Casa de Velasquez.

Sherratt, A., and S. Sherratt. 1988. "The Archaeology of Indo-European: An Alternative View." Antiquity 62(236): 584-95.

Sjögren, K.-G., T.D. Price, and K. Kristiansen. 2016. “Diet and Mobility in the Corded Ware of Central Europe." PLoS ONE 11(5):e0155083. https://doi.org/10.1371/journal. pone. 0155083 .

Skoglund, P., H. Malmström, M. Raghavan, J. Storå, P. Hall, E. Willerslev, M. Thomas, P. Gilbert, A. Götherström, and M. Jakobsson. 2012. "Origins and Genetic Legacy of Neolithic Farmers and Hunter-Gatherers in Europe." Science 336(6080):466-69. https://doi.org/10.1126/science. 1216304.

Treherne, P. 1995. “The Warrior's Beauty: The Masculine Body and Self-Identity in Bronze-Age Europe." Journal of European Archaeology 3(1):105-44.

Vandkilde, H. 1996. From Stone to Bronze: The Metalwork of the Late Neolithic and Earliest Bronze Age in Denmark. Jutland Archaeological Society Publications 32. Højbjerg, Denmark: Jutland Archaeological Society and Aarhus University Press.

2007. Culture and Change in Central European Prehistory: 6th to 1st Millennium BC. Aarhus: Aarhus University Press.

_. 2011. "Bronze Age Warfare in Temperate Europe." In Sozialarchäologische Perspektiven: Gesellschaftlicher Wandel 5000-1500 v. Chr. zwischen Atlantik und Kaukasus, edited by S. Hansen and J. Müller, 365-80. Archäologie in Eurasien 24. Darmstadt, Germany: Deutsches Archäologisches Institut, Eurasien-Abteilung.

Whittle, A. 1996. Europe in the Neolithic: The Creation of New Worlds. Cambridge World Archaeology. Cambridge: Cambridge University Press.

Zich, B. 1993. "Die Ausgrabungen chronisch gefährdeter Hügelgräber der Stein- und Bronzezeit in Flintbek, Kreis Rendsburg-Eckernförde Ein Vorbericht." Offa 49-50: $15-31$.

Zohary, D., and M. Hopf. 2000. Domestication of Plants in the Old World. 3rd ed. Oxford: Oxford University Press. 